\title{
RECORDS OF INVASIVE EUROPEAN CATFISH Silurus glanis (LINNAEUS, 1758) IN THE NERETVA RIVER DELTA (CROATIA): SOCIAL MEDIA AS INFORMATION SOURCE
}

\author{
Pero Tutman ${ }^{1}$, Branko Dragičević ${ }^{1 *}$, Jakov Dulčić ${ }^{1}$, Višnja Bukvić ${ }^{2}$, Vitaly Bekh ${ }^{3}$, Branko Glamuzina ${ }^{4}$
}

${ }^{1}$ Institute of Oceanography and Fisheries, Laboratory for Ichthyology and Coastal Fisheries, Šetalište Ivana Meštrovića 63, 21000 Split, Croatia

${ }^{2}$ University of Herzegovina, Blajburških žrtava 100, 88000 Mostar, Bosnia and Hercegovina

${ }^{3}$ National University of Life and Environmental Sciences of Ukraine, Aquaculture Department Heroyiv Oborony str., 15, Kyiv-03041, Ukraine

${ }^{4}$ University of Dubrovnik, Department for Aquaculture, Ćira Carića 4, 20000 Dubrovnik, Croatia

*Corresponding Author: brankod@izor.hr

\section{ARTICLE INFO}

Received: 25 September 2020

Accepted: 28 October 2020

Keywords:

First record

Alien species

Adriatic Sea basin

Management control

\section{ABSTRACT}

Records of European catfish Silurus glanis in the Neretva River delta (Adriatic Sea basin) in Croatia are reported. The first occurrence of this non-native species was reported via social network which led to its timely detection by researchers. Origin of introduction is unknown but it is most likely the case of human-mediated introduction. The importance of social networks as a useful tool for the timely detection of non-native fish species, as well as the importance of raising awareness about the impacts of biological invasions, is discussed in this paper.

Tutman, P., Dragičević, B., Dulčić, J., Bukvić, V., Bekh, V., Glamuzina, B. (2021): Records of invasive European catfish Silurus glanis (Linnaeus, 1758) in the Neretva River delta (Croatia): Social media as information source. Croatian Journal of Fisheries, 79, 47-52. DOI: 10.2478/cjf-2021-0005. 


\section{INTRODUCTION}

The modern age of the Internet and digital communication technologies has brought about a significant increase in both the speed and efficiency of information exchange. Social networking sites, i.e. Facebook, Twitter and Flickr, have proven to be an exceptional source of quality information for scientists documenting biodiversity (Barve, 2014). Such platforms have been especially important for early detection and subsequent tracking of non-indigenous species in the marine (Azzurro et al., 2013; Bariche and Azzurro, 2016; Langeneck et al., 2017) and freshwater environment (Dulčić et al., 2017) that otherwise would have hardly been obtained through regular scientific sampling (Dulčić et al., 2018). As nonindigenous species can remain undetected for years after initial colonization (Crooks, 2005), the ability to timely detect such occurrences is essential for successful mitigation of their impacts. Indeed, information obtained through social networks has already enabled early detection of non-native species in the area of the Neretva River delta in Croatia (Dulčić et al., 2017; Dulčić et al., 2018).

The introduction of non-native freshwater fish species caused by human activities represents one of the most serious threats to biodiversity and ecosystem integrity in different parts of Europe, but also worldwide (Clavero and García-Berthou, 2005; Gozlan et al., 2010; Ribeiro and Leunda, 2012). Non-native species usually have a high potential for dispersion and can impact native species by occupying their ecological niches as the former usually have competitive advantages over the latter and benefit from the absence of predators (Moyle and Light, 1996). Additionally, adverse ecological impacts on native species can also be imposed by non-natives through habitat alteration and importation, and movement of pathogens and parasites (Moyle et al., 1987).

The wide area of the Neretva River delta has been recognized as a very important freshwater wetland habitat in the Mediterranean karst area of Croatia (Mrakovčić et al., 1995; Smith and Darwall, 2006) and Bosnia and Herzegovina (Glamuzina et al., 2017). It supports rich ichthyoplankton and highly diverse fish community, as well as important commercial fisheries (Dulčić et al., 2007; Dulčić and Glamuzina, 2010). This wetland also hosts several protected ornithological and ichthyological reserves and is considered as one of the most important wetlands in Europe for resting and wintering of migratory birds (Stumberger and Schneider-Jacoby, 2010). However, this area also suffers from uncontrolled introduction of freshwater (Dulčić et al., 2011; Dulčić and Tutman, 2015; Dulčić et al., 2017) and marine non-native species (Onofri et al., 2008; Cukrov et al., 2010; Despalatović et al., 2013) which pose a threat to the natural equilibrium of the delta community.

European catfish Silurus glanis (Linnaeus, 1758) is native to the North, Baltic, Black, Caspian and Aral Sea drainages but has been introduced and translocated throughout Europe and the Balkhash basin (Kazakhstan) (Kottelat and Freyhoff, 2007). Although native to rivers of Eastern Europe and Western Asia, it is currently being introduced worldwide due to its popularity among anglers and interest as a potential species for aquaculture (Alp et al., 2011). This species appears sufficiently robust for translocation and introduction outside its native range. It is the largest European freshwater fish and due to its piscivorous diet, it is assumed to pose a threat to native species and ecosystems (Copp et al., 2009). In Croatia and Bosnia and Herzegovina, it is native in the Danube basin but it has also been introduced in the lakes of the Adriatic basin, namely Vransko Lake near Biograd and Perućko Reservoir in the Cetina River basin (Sofradžija, 2009; Pofuk et al., 2017; Ćaleta et al., 2019). In Bosnia and Herzegovina, it has been introduced in Buško Blato Reservoir in the Cetina River basin (Aganović et al., 1974) and Bilećko Lake Reservoir in the Trebišnjica River basin (Hamzić et al., 2008). Recently it has also been introduced in the Hutovo Blato wetland (Glamuzina et al., 2010).

The aim of this study is to present the first record of nonnative S. glanis from the Neretva River delta (Adriatic Sea basin), indicating an extension of the known distribution of this species in Croatia. Additionally, the role of social networks in obtaining and transmitting information essential for tracking biodiversity changes is discussed.

\section{MATERIAL AND METHODS}

On 15 April 2018, a photograph of a fish was posted by a fisherman in the Facebook group titled "Morski ribolov" (Eng. Marine fisheries), with a request for its identification. The specimen was caught in the area close to the Neretva River delta $\left(42^{\circ} 9733 \mathrm{~N}, 17^{\circ} 6075 \mathrm{E}\right.$; Fig. 1 - Location 1$)$.

The features which helped identify the species as Silurus glanis were as follows: elongated body, mottled body colour pattern and particularly long and emarginated anal fin and long barbels (Fig. 2). These were in agreement with the description provided by Kottelat and Freyhof (2007). After the identification, the fisherman who posted the photograph was contacted and additional data on this, but also on other occurrences of the same species, were obtained. The photographed individual of S. glanis was approximately $30 \mathrm{~cm}$ long (TL) and weighed $0.30 \mathrm{~kg}$. Unfortunately, additional data, such as those on habitat type and water temperature were not available. According to the fisherman's statement, in the same catch, approx. 10 specimens of $S$. glanis were caught along with other non-native fish species such as Ameiurus nebulosus (Linnaeus, 1758) and Micropterus salmoides (Linnaeus, 1766). Additionally, a photo of another specimen, previously caught near Lake Kuti, was also provided by the fisherman. Upon this realization, other fishermen operating in the same area were contacted.

Several of these fishermen confirmed the presence of $S$. glanis in the wider area of the Neretva River delta in the 
recent period and one provided an additional photo of a large specimen caught in the area of the Hutovo Blato. None of the specimens were preserved.

Through a web search, a media article reporting a catch of a large specimen ( $150 \mathrm{~cm}$ TL and weighing over $20 \mathrm{~kg}$ ) caught in the wider area of the Neretva River delta was found. In this article, the fisherman stated that other catches of the same species occurred in the area (http:// metkovic-news.com/news/nas-poznati-ribolovac-antekrsticevic-baja-ulovio-soma-od-metar-i-pol-teskog-preko$20-\mathrm{kg} /$ ).

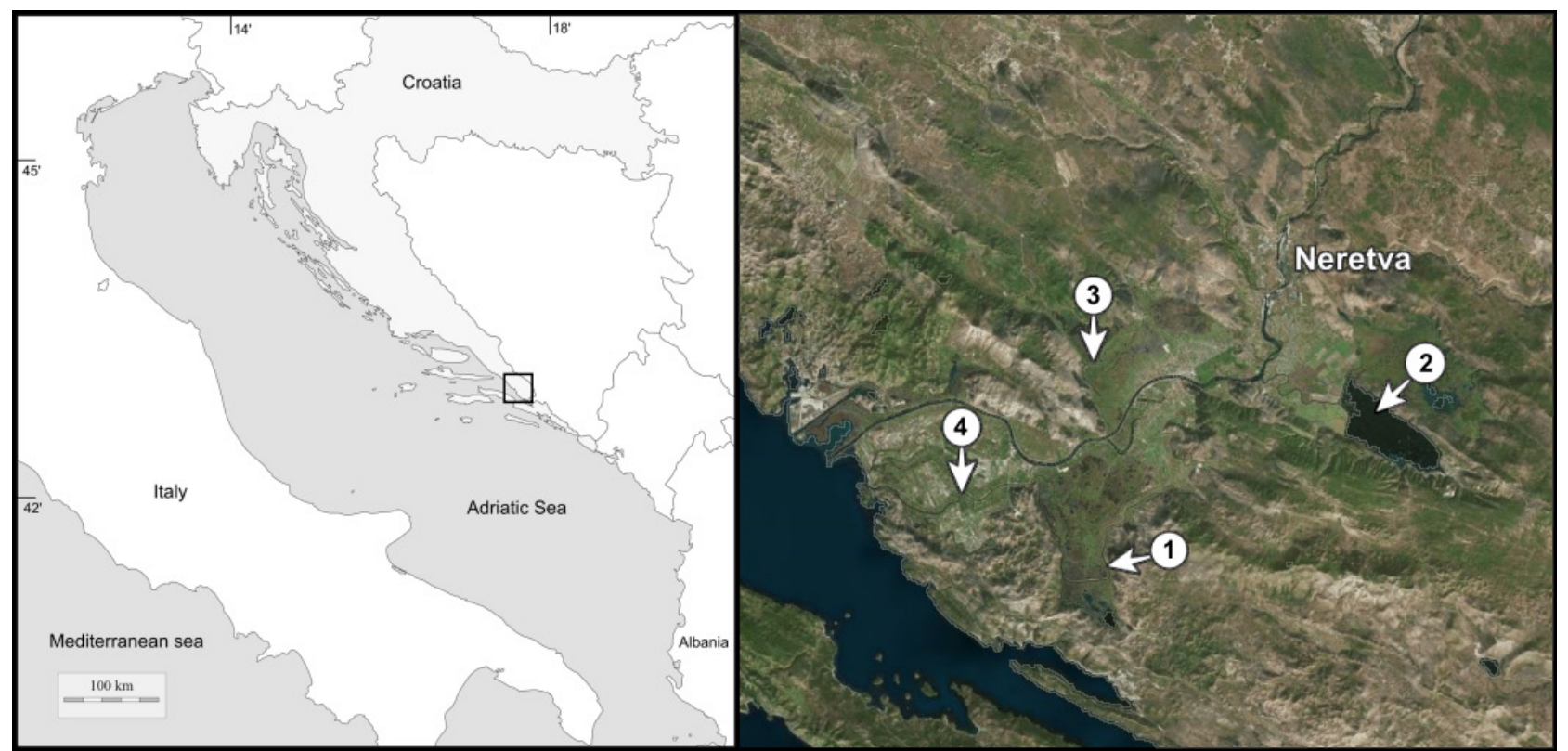

Fig 1. Location of the area where occurrences of S. glanis have been recorded. Numbers correspond to the locations indicated in the paper

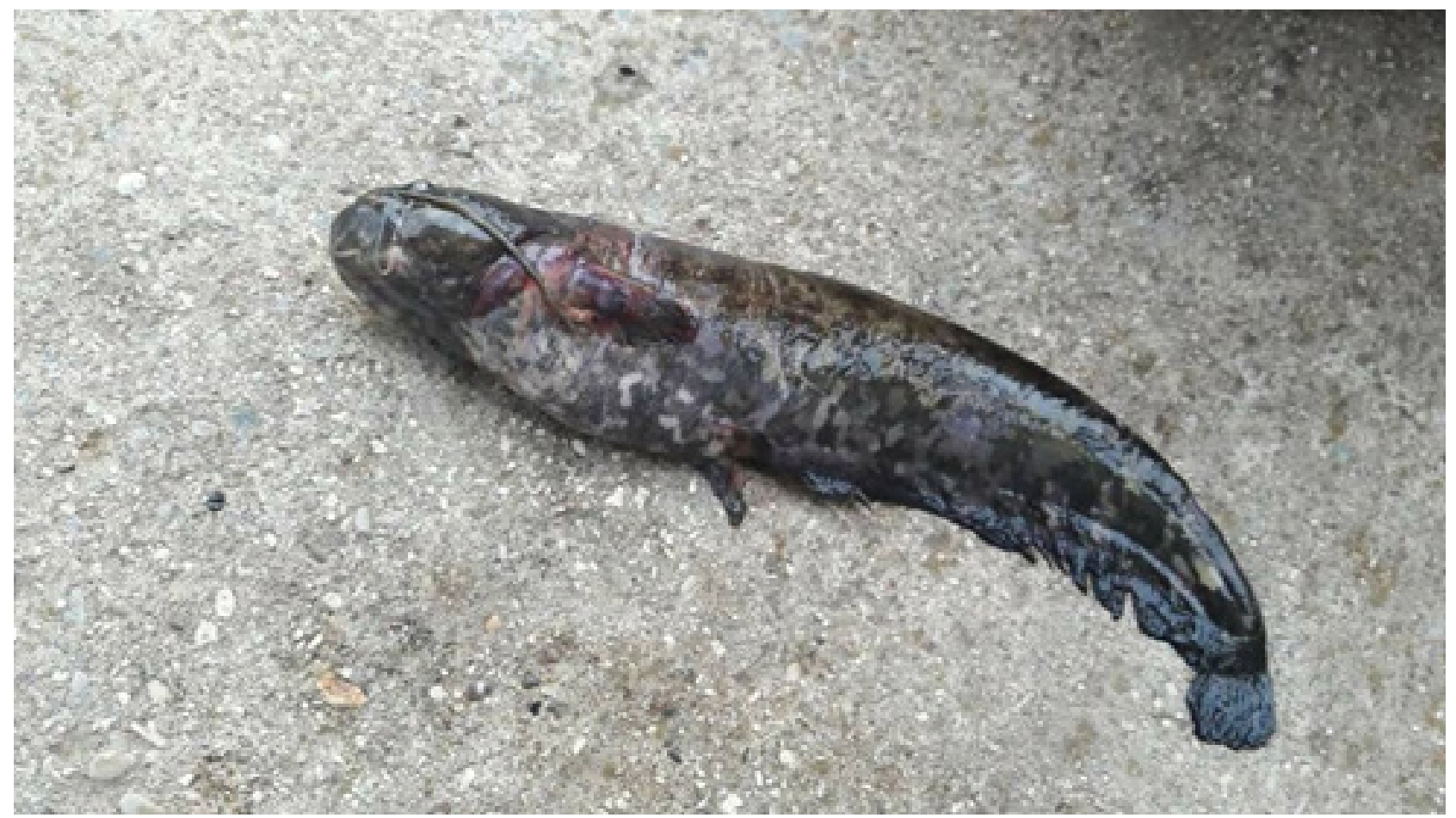

Fig 2. The specimen of Silurus glanis caught in the area of Neretva River delta on 15 April 2018. This photo was posted by the fisherman in the Facebook group "Morski ribolov" 


\section{RESULTS AND DISCUSSION}

The modern age has brought significant changes in the field of digital innovation, especially in the development of social communication media, which have opened up large and numerous opportunities in obtaining data valuable to research and conservation. Social networks have become an increasingly important source of information relevant to researchers that would otherwise go unnoticed. This has been especially important in tracking occurrences of non-indigenous species, as already evidenced through many studies (e.g. Dulčić et al., 2017; Dulčić et al., 2018; Langeneck et al., 2017). Interest groups on social networks (i.e. Facebook), oriented toward fishery, biodiversity or other related topics, have provided a common place for sharing photos and videos of various species and in such a way have greatly improved the odds of early detection of those species which are non-native. This means of obtaining information has been especially important in cases and particular areas where no comprehensive and targeted monitoring system has been deployed. Recording and reporting species in non-native areas represents the initial step in the process of preventing invasions or mitigating their consequences (Banha et al., 2015). To raise the possibility of reporting such occurrences by the local community, it is also essential to spread the information about the importance of reporting such findings to researchers. In our case, such a step has already been initiated through contacts with local fishermen to whom such information has been provided. In this area, there has been no specific sampling network established for non-native species detection. Therefore, reports by local people may provide valuable information, complementing other sources and improving monitoring and action plans dealing with aquatic invasions. Such reports have also proven to be valuable in cases of largemouth bass Micropterus salmoides (Lacépède, 1802) and featherfin squeaker Synodontis eupterus (Boulenger, 1901) which came to the attention of scientists through reports shared on social network (Dulčić et al., 2017, 2018).

Silurus glanis is native to the Danube basin in Bosnia and Herzegovina and Croatia, but it has been introduced and translocated in freshwaters throughout the Adriatic Sea basin where it is considered invasive (Glamuzina et al., 2017; Pofuk et al., 2017). Because of its ability to adapt and robustness which facilitates its translocation and introduction into new habitats, established populations outside of its native range are known to cause negative effects in the new environment (Copp et al., 2009). As a voracious predator, invasive $S$. glanis can disrupt the native ecology of the systems to which they have been introduced. The risk that $S$. glanis poses to the native fauna includes a decrease of abundance of native fish and other vertebrates (i.e. amphibians) through predation and competitive advantage and indirect alteration of planktonic and benthic communities through its effects on the food chain (Kottelat and Freyhof, 2007; Carol et al.,
2009; Almeida et al., 2013).

The origin of S. glanis in the Neretva River delta area has not been established with certainty. It is a widespread and highly valued species in sportive and recreational fishery in its native range in the Danube basin in Croatia (Ćaleta et al., 2019). It is also known to be used for illegal stocking. Given the length range of recorded specimens (ranging from approx. 30 to $150 \mathrm{~cm}$ ) and taking into account the fact that at a length of $30 \mathrm{~cm}$ catfish is still in its juvenile phase (Alp et al., 2004), it could be suggested that this area hosts an established population of the species. Anecdotal evidence on the previous occurrences of $S$. glanis in the Neretva River delta suggests it was first recorded in 2011 from the River Norin (a right-hand tributary of the lower River Neretva; Fig. 1 - Location 2) (Glamuzina, unpublished data). Some years previously, catfish were introduced for sport fishing into the Hutovo Blato wetland in Bosnia and Herzegovina (lower Neretva River basin) (Glamuzina et al., 2010), where it is now frequent (Glamuzina, unpublished data). The fishermen's observations suggest possible establishment in the shallow and warmer River Mala Neretva wetland area (Neretva River delta; Fig. 1 - Location 3). Recently, it has also been recorded in a reservoir in the middle Neretva River basin and further upstream in Jablaničko Reservoir in Bosnia and Herzegovina (Glamuzina, unpublished data). Data presented in this study, together with occasional records in other estuarine and riverine areas of the region, suggest that invasion by this species may be limited to shallow, warmer and slightly brackish estuarine areas. Additionally, it seems that following its introduction, this species subsequently became economically relevant locally, evidenced by its price at fish markets of $50 \mathrm{HRK} / \mathrm{kg}$ (approx. 7 EUR per kg).

Intentional and unintentional introductions by anglers have been major drivers behind the spread of $S$. glanis (Carol et al., 2009). Anglers intentionally introduce this species to create more fishing opportunities, without considering the potential impacts. At present, the impacts of $S$. glanis on the native ecosystem are unknown and should be investigated in the future.

Besides the expansion of non-indigenous species in the Neretva River delta (Onofri et al., 2008; Cukrov, 2010; Despalatović et al., 2013; Dulčić and Tutman, 2015; Dulčić et al., 2011, 2017, 2018), this area has also been exposed to various other anthropogenic stressors such as organic and nutrient pollution and contamination from agriculture and local industries, and hydromorphological degradation of habitats (Mateljak and Matić, 2011). Saltwater intrusion deep through the Neretva River delta (Glamuzina et al., 2019; Glamuzina and Dobroslavić, 2020), as a result of anthropogenic influence and climate change, represents an additional threat to the ecosystem.

Despite rich biodiversity in the area, threatened by an increasing number of non-native species, there are no species monitoring and detection networks established. Therefore, additional sources of information such as those 
obtained through social networks have proven to be of great value in early detection of non-native species. Also, there is an urgent need for additional research aimed at the detection and evaluation of impacts of such species. Data obtained through such research should provide a basis for mitigation of impacts of non-native species, especially those which prove to be invasive. To achieve the desired goals, monitoring of the $S$. glanis spreading and the potential effect on the environment and local fishery in the Neretva River delta is strongly recommended.

\section{ACKNOWLEDGEMENTS}

This work has been supported by Croatian Science Foundation (HRZZ) under the project IP-2016-06-5251. We wish to thank all the fishermen who provided valuable information about the $S$. glanis occurrences, especially Mr Marinko and Mrs Sandra Curić (Opuzen, Croatia) who provided valuable data.

\section{NALAZI INVAZIVNOG EUROPSKOG SOMA, Silurus glanis (LINNAEUS, 1758.), U DELTI RIJEKE NERETVE, HRVATSKA: INFORMACIJE PRIKUPLJENE KROZ DRUŠTVENE MREŽE}

\section{SAŽETAK}

$\mathrm{U}$ radu se prikazuju nalazi europskog soma Silurus glanis u delti rijeke Neretve (sliv Jadranskog mora) u Hrvatskoj. Pojava ove nezavičajne vrste prijavljena je putem društvene mreže, što je dovelo i do pravovremenog otkrivanja od strane istraživača. Podrijetlo unosa vrste nije poznato, ali najvjerojatnije se radi o namjernom unosu posredstvom čovjeka. U radu se govori o važnosti društvenih mreža kao korisnog alata za pravovremeno otkrivanje nezavičajnih vrsta riba, kao i o važnosti podizanja svijesti o utjecajima bioloških invazija.

Ključne riječi: prvi zapis, strane vrste, sliv Jadranskog mora, kontrola upravljanja

\section{REFERENCES}

Aganović, M., Kosorić, Đ., Vuković, T., Mučibabić, S., Marinković-Gospodnetić, M., Šenk, O., Jerković, L., Radulović, V., Čanković, M., Kaćanski, D., Riter, M., Zupčević, O., Krek, S., Petković, S., Kapetanović, N., Veledar, I., Tanasijević, M., Čepić, V., Remeta, D. (1974): Gospodarska osnova ribarstva na akumulaciji Buško Blato i kompenzacionom bazenu Lipa. Biološki institut Univerziteta u Sarajevu, Sarajevo, 236 (in Bosnian).

Almeida, D., Riberio, F., Leunda, P.M., Vilizzi, L., Copp G. (2013): Effectiveness of FISK, an invasiveness screening tool for non-native freshwater fishes, to perform risk identification assessments in the Iberian Peninsula. Risk Analysis, 33, 8, 1404 - 1413.
Alp, A., Kara, C., Büyükçapar, H. M. (2004): Reproductive biology in a native European catfish, Silurus glanis L., 1758, population in Menzelet Reservoir. Turkish Journal of Veterinary and Animal Sciences, 28, 3, 613 - 622.

Alp, A., Kara, C., Ückardes, F., Carol, J., Garcia-Berthou, E. (2011): Age and growth of the European catfish (Silurus glanis) in a Turkish reservoir and comparison with introduced populations. Reviews in Fish Biology and Fisheries, 21, 2, 283-294.

Azzurro E., Broglio E., Maynou F., Bariche M. (2013): Citizen science detects the undetected: the case of Abudefduf saxatilis from the Mediterranean Sea. Management of Biological Invasions, 4, 2, 167 - 170.

Bariche, M., Azzurro, E. (2016): Enhancing early detection through social networks: a Facebook experiment. Rapp. Comm. Int. Mer. Médit. 41, 413.

Barve, V. (2014): Discovering and developing primary biodiversity data from social networking sites: A novel approach. Ecological Informatics, 24, 194 - 199.

Banha, F., Ilhéu, M., Anastácio, P. M. (2015): Angling web forums as an additional tool for detection of new fish introductions: the first record of Perca fluviatilis in continental Portugal. Knowledge and Management of Aquatic Ecosystems, 416, 03.

Carol, J., Benejam, L., Benito, J., García-Berthou, E. (2009): Growth and diet of European Catfish (Silurus glanis) in early and late invasion stages. Fundamental and Applied Limnology, 174, 4, 317 - 328.

Clavero, M., García-Berthou, E. (2005): Invasive species are a leading cause of animal extinctions. Trends in Ecology and Evolution 20, 3, 110.

Copp, G. H., Britton, J. R., Cucherousset, J., García-Berthou, E., Kirk, R., Peeler, E. and Stakènas, S. (2009): Voracious invader or benign feline? A review of the environmental biology of European catfish Silurus glanis in its native and introduced ranges. Fish and Fisheries, 10, 3, 252 $-282$.

Crooks, J. A. (2005): Lag times and exotic species: The ecology and management of biological invasions in slow-motion1. Ecoscience, 12, 3, 316- 329.

Cukrov, M., Despalatović, M., Žuljević, A., Cukrov, N. (2010): First record of the introduced fouling tubeworm Ficopomatus enigmaticus (Fauvel, 1923) in the eastern Adriatic Sea, Croatia. Rapp. Comm. int. Mer. Médit., 39, 483.

Ćaleta, M., Marčić, Z., Buj, I., Zanella, D., Mustafić, P., Duplić, A., Horvatić, S. (2019): Extant Croatian freshwater fish and lampreys- Annotated list and distribution. Croatian Journal of Fisheries, 77, 3, 137 - 234.

Despalatović, M., Cukrov, M., Cvitković, I, Cukrov, N., Žuljević, A. (2013): Occurrence of non-indigenous invasive bivalve Arcuatula senhousia in aggregations of non-indigenous invasive polychaete Ficopomatus enigmaticus in Neretva River Delta on the Eastern Adriatic coast. Acta Adriatica, 54, 2, 213 - 219.

Dulčić, J., Tutman, P., Matić-Skoko, S., Kraljević, M., JugDujaković, J., Glavić, N., Kožul, V., Glamuzina, B., 
Bartulović, V., Skaramuca, B. (2007): A list of Y-O-Y fish species found in the littoral shallows of the Neretva and Mala Neretva estuaries (Eastern Adriatic, Croatian coast). Acta Adriatica, 48, 1, 89 - 94.

Dulčić, J., Glamuzina, B. (2010): Vulnerability assessments of the fisheries sector to climate change: case of the broader Neretva River delta. U: Glamuzina, B., Dulčić, J. (eds), Ribe i Ribarstvo, rijeke Neretve. Sveučilište u Dubrovniku i Dubrovačko neretvanska županija, Dubrovnik, 31 - 38pp. (in Croatian)

Dulčić, J., Tutman, P., Matić-Skoko, S., Glamuzina, B. (2011): Six years from first record to population establishment: the case of the blue crab, Callinectes sapidus Rathbun, 1896 (Brachyura, Portunidae) in the Neretva River delta (southeastern Adriatic Sea, Croatia). Crustaceana, 84, 10, 1211 - 1220.

Dulčić, J., Tutman, P. (2015): Additional record of common bream Abramis brama (Cyprinidae) in the Adriatic drainage system (Norin River, Croatia). Annales, Series historia naturalis, 25, 2, 145 - 148.

Dulčić, J., Dragičević, B., Ugarković, P., Tutman, P. (2017): The largemouth black bass (Micropterus salmoides) first record in the Neretva River delta, Adriatic drainage system of Croatia. Cybium, 41, 1, 77- 78.

Dulčić, J., Tutman, P., Dragičević, B. (2018): On the occurrence of the Synodontis eupterus (Mochokidae) in the Adriatic drainage system of Croatia: a case of an introduced aquarium species and suggestions for alien species detection measures. Cybium, 42, 3, $297-298$.

Glamuzina, B., Tutman, P., Pavličević, J., Bogut, I., Dulčić, J. (2010): Bioraznolikost riba Hercegovine. U: Herceg, N. (eds) Međunarodni kolokvij "2010.- godina bioraznolikosti"; 2011, Sarajevo, Federalno ministarstvo okoliša i turizma, 119 - 135 (in Bosnian).

Glamuzina, B., Tutman, P., Nikolić, V., Vidović, Z., Pavličević, J., Vilizzi, L., Copp, G.H., Simonović, P. (2017): Comparison of taxon-specific and taxon-generic risk screening tools to identify potentially invasive nonnative fishes in the River Neretva catchment (Bosnia and Herzegovina and Croatia). River Research and Applications, 33, 5, 670-679.

Glamuzina, B., Dobroslavić, T., Bukvić, V., Tutman, P., Bartulović, V. (2019): Rare records of mature Sea lamprey, Petromyzon marinus Linnaeus, 1758 during migration in the River Neretva (Croatia, Bosnia and Herzegovina). Cahiers de Biologie Marine, 60, 399 402.

Glamuzina, L., Dobroslavić, T. (2020): Summer Fish Migrations in the River Neretva (South-Eastern Adriatic Coast, Croatia) as a Consequence of Salinization. Naše more, 67, 2, 103 - 116.

Gozlan, R. E., Britton, J. R., Cowx, I., Copp, G. H. (2010): Current knowledge on non-native freshwater fish introductions. Journal of Fish Biology, 76, 4, 751 - 756.

Hamzić, A., Lelo, S., Hasković, E., Skaramuca, B. (2008): Alohtone vrste slatkovodnih riba rijeka Trebišnjice i Neretve (BiH). U: Skaramuca, B., Dulčić, J. (eds.),
Zbornik radova znanstveno - stručnog skupa "Ugrožene i endemske vrste riba u slivovima rijeka Neretve, Trebišnjice i Morače". Dubrovnik, Sveučilište u Dubrovniku, EastWest Institute, 91 - 101 (in Bosnian).

Kottelat, M., Freyhof, J. (2007): Handbook of European Freshwater Fishes. Kottelat, Cornol, Switzerland and Freyhof, Berlin, Germany, pp. 569 - 570.

Langeneck, J., Marcelli, M., Bariche, M., Azzurro, E. (2017): Social networks allow early detection of non indigenous species: first record of the red drum Sciaenops occellatus (Actinopterygii: Perciformes: Sciaenidae) in Italian waters. Acta Adriatica, 58, 2, 365 - 370.

Mateljak, Z., Matić, S. (2011): Neretva Delta - Croatia/ Bosnia and Herzegovina - Feasibility study on establishing transboundary cooperation. Gland, Switzerland, and Belgrade, Serbia: IUCN Programme Office for South-Eastern Europe, pp 32.

Moyle, P. B., Li, H. W., Barton, B. (1987): The Frankenstein effect: impact of introduced fishes on native fishes of North America. U: Stroud, R. H. (ed.), The Role of Fish Culture in Fisheries Management. American Fisheries Society Symposium, Bethesda, 415 - 426.

Moyle, P. B., Light T. (1996): Biological invasions of fresh water: empirical rules and assembly theory. Biological Conservation, 78, 1-2, 149 - 161.

Mrakovčić, M., Mišetić, S., Povž, M. (1995): Status of freshwater fish in Croatian Adriatic river systems. Biological Conservation, 72, 2, 179- 185.

Onofri, V., Dulčić, J., Conides, A., Matić-Skoko, S., Glamuzina, B. (2008): The occurrence of the blue crab, Callinectes sapidus Rathbun, 1896 (Decapoda, Brachyura, Portunidae) in the eastern Adriatic (Croatian coast). Crustaceana, 81, 4, 403 - 409.

Pofuk, M., Zanella, D., Piria, M. (2017): An overview of the translocated native and non-native fish species in Croatia: pathways, impacts and management. Management of Biological Invasions, 8, 3, 425-435.

Ribeiro, F., Leunda, P. M. (2012): Non-native fish impacts on Mediterranean freshwater ecosystems: current knowledge and research needs. Fisheries Management and Ecology, 19, 2, $142-156$.

Smith, K. G., Darwall, W. R. T. (2006): The status and distribution of freshwater fish endemic to the Mediterranean basin. IUCN, Gland, Switzerland and Cambridge, UK.

Sofradžija, A. (2009): Slatkovodne ribe Bosne i Hercegovine. Vijeće Kongresa bošnjačkih intelektualaca, Sarajevo. (In Bosnian). 353.

Stumberger, B., Schneider-Jacoby, M. (2010): International importance of three Adriatic Flyway priority sites: Livanjsko Polje, the Neretva Delta and Lake SkadarShkoder with the Bojana-Buna Delta. U: Denac, D., Schneider-Jacoby, M. \& Stumberger, B. (eds.). Adriatic flyway; closing the gap in bird conservation. Euronatur, Radolfzell, 53 - 58. 